\title{
発芽玄米・発芽大麦混合利用による粉末の製造とその高血圧抑制効果 ${ }^{\dagger}$
}

\author{
安井裕次 ${ }^{\S}$, 鈴木啓太郎*，岡留博司*, 奥西智哉*, 橋本勝彦, 大坪研一* \\ 吉村穀粉株式会社 \\ *独立行政法人食品総合研究所
}

\begin{abstract}
Preparation of Co-extruded Flours Using Germinated Brown Rice and Barley and its Antihypertensive Effect

(Research on development for applications of germinated brown rice Part II)
\end{abstract}

\author{
Yuji Yasui ${ }^{\S}$, Keitaro Suzuki*, Hiroshi Okadome*, Tomoya Okunishi*, \\ Katsuhiko Hashimoto and Ken'ichi Ohtsubo* \\ Yoshimura Kokufun Co.Ltd.,2-1501,Fushiya, Nakagawa, Nagoya, Aichi 454-0996 \\ * National Food Research Institute, 2-1-12, Kannondai, Tsukuba, Ibaraki 305-8642
}

\begin{abstract}
A mixture of germinated brown rice and germinated barley (A) and a mixture of germinated brown rice, germinated barley and beer yeast (B) were puffed using a twin-screw extruder to develop high bio-functional powders. Through extrusion under high-temperature and high-pressure, fine granular distribution of the extrudates and suppression of bacterial growth were available. An increase of fatty acidity during storage was inhibited and digestibility was enhanced. The extrudates A and B contained phytic acid, inositol, ferulic acid, and dietary fibers more than the germinated brown rice. In a feeding test using SHR rats, antihypertensive effects were shown in the exrudates B. As for a panel test of bread which contained $30 \%$ of the combined extrudate powder, extrudate A bred was significantly superior to the bread of $100 \%$ of flour in texture $(\mathrm{P}<0.05)$ and sweetness $(\mathrm{P}<0.05)$ of the products. Compared with germinated brown rice, the bio-functionality was significantly strengthened in the mixtures $\mathrm{A}$ and $\mathrm{B}$.
\end{abstract}

(Received Mar. 29, 2004 ; Accepted Aug. 6, 2004)

我が国の米の 1 人当たりの消費量は, 昭和 37 年をピー クに以降一貫して減少している。具体的には，37 年度には 1 人当たり年間 118 キログラムの米を消費していたが，平 成 14 年度には, その半分近くの 62 キログラムにまで減少 している. 消費減少の要因としては, 近年, 食生活が多様 化するとともに, 食の欧米化が進んでいるためと推測され る. その結果, 栄養バランスが崩れることにより, 生活習 慣病が増大する傾向にある，そのため，米を中心とした日 本型食生活の良さを見直すことが今まで以上に重要となっ ている, 現在では, 近畿, 東海, 関東, 東北等, 全国各地 で米粉食品の利用推進協議会が設立され, 米の用途拡大,

新しい加工技術の開発が期待されている.

最近, 新しい加工技術の開発により, 高い機能性をもつ 発芽玄米の消費が増加している，米胚芽を水に浸漬して発 芽させることにより, 酵素が一斉に活性化し, 胚芽部分の

\footnotetext{
†発芽玄米の新用途開発に関する研究（第 2 報）（前報，文献 7)）

T454-0996 愛知県名古屋市中川区伏屋 2-1501

* \%305-8642 茨城県つくば市観音台 2-1-12

$\S$ 連絡先 (Corresponding author), TEL : 052-301-7676
}

$\gamma$-アミノ酪酸（ $\gamma$-aminobutyric acid, 以下 GABA と記述 する）含有量が高まり ${ }^{1)}$, 玄米の約 2 倍, 白米の約 10 倍以 上となる. GABA は, 高血圧症予防, 中性脂肪の増加の抑 制, 精神安定作用等の効果 ${ }^{23)}$ があるとされ, 機能性成分と して注目されている。しかし, 発芽玄米には, 菌の付着や 米飯の外観, 食感が硬いという物性上の欠点などが問題に なる場合がある。

一方，大麦は，食物繊維を多く含み，その含有量は白米 の約 19 倍4) である。一般には穀物が含む食物繊維は, 不溶 性の割合が高く, 水溶性の割合が低いが，大麦の場合，両 方をバランス良く含んでいる。水溶性食物繊維は，コレス テロール や血糖值を下げる作用があるため，糖尿病や動 脈硬化症, 胆石症などの予防に効果があり, 不溶性食物繊 維は便の量を増やして便秘や大腸ガンを予防するなど，生 活習慣病にさまざまな作用と効果のあることが報告されて いる.

ビール酵母は長年にわたる機能性研究により, ビタミン B1，B2，B6 など，人体の生理機能を調整するビタミン B 群や, 成長に欠かせない必須アミノ酸, ミネラル, 食物繊 
維に富むことが明らかにされた。生理機能に関する研究で は, 動物試験と臨床試験により栄養補給, 胃腸機能の改善, 分血の改善, 肝機能の改善, 糖尿病, 高脂血症の治療効果 等が明らかにされてきた。 また，ビ一ル酵母を継続的に摂 取することにより, 血液中のインシュリン濃度が適正に保 たれ，肥満予坊効果があると報告されていることから ${ }^{6}$, 機能性食品の原料として注目が高まっている.

本研究の目的は, 米および大麦を発芽させ, 増加した機 能性成分を互いに補い合いながら，さらに強化成分として 粉末ビール酵母を加えて高温高圧加工（膨化処理）を行な うことにより, 生理機能性, 消化性および衛生性に優れた, 多目的食品素材の製造技術を開発することにある.

\section{実 験 方 法}

\section{1. 試料の発芽処理}

米は平成 15 年岐阜県産ハッシモ，大麦は平成 15 年に四 国研究センター（裸麦育種研究室）で生産されたダイシモ チを供試した，立米 $2.5 \mathrm{~kg}$ および大麦 $1.5 \mathrm{~kg}$ をそれぞれ $0.1 \%$ 次亜塩素酸ナトリウム水溶液にて 30 分間浸漬殺菌し た. 水で十分洗浄した後, $30^{\circ} \mathrm{C}$ に制御した $120 \mathrm{~L}$ の水に浸 漬した. 浸漬水は玄米, 大麦ともに 24 時間に 1 回全量交換 を行った. 発芽処理時間は玄米, 大麦ともに 72 時間浸漬し たものを使用した。

\section{2. 水分調整}

発芽処理後の玄米および大麦を十分に水で洗浄後, $15^{\circ} \mathrm{C}$ に設定をした環境試験室（三洋電機メディカシステムズ株 式会社）にて乾燥を行い，水分含量は $10 \%$ から $13 \%$ の範 囲で調整を行なった．試料の水分測定は，八ロゲン水分計 （METTLER TOLEDO, HR73）により計測を行なった.

\section{3. 試料調製}

膨化処理に供試する試料として，水分調整を行った発芽 玄米と発芽大麦および乾燥粉末ビール酵母（武田キリン株 式会社製）を用いた。発芽玄米, はだか麦の加工特性の研 究より良好な膨化物が得られたとの報告7)8 米のGABA，イノシトール等, 発芽大麦の食物緎維, 総 フェルラ酸等により両者を混合することによる生理機能性 の強化を目的とし, 発芽玄米, 発芽大麦を $5: 5$ と配合した 試料（以下, 混合 A と記述する）と, 発芽玄米にビール酵

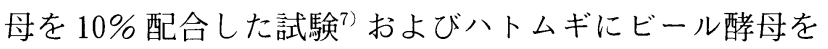
10\%，15\% 配合した予備試験 ${ }^{9)} に よ り ，$ 膨化性を損なわな い結果を得ることが出来たため, 発芽玄米, 発芽大麦, 乾 燥粉末ビール酵母を $4.25: 4.25: 1.5$ に配合した試料（以 下, 混合 B と記述する）の 2 種類を混合膨化原料として調 製を行なった。

\section{4. 膨化処理}

膨化処理は 2 軸エクストルーダー（日本製鋼株式会社 製，TEX30FC-18.5）にて実施した．本装置は内径 $30 \mathrm{~mm}$, 長径比 $\mathrm{L} / \mathrm{D}=18.5$ の仕様で, 径 $4 \mathrm{~mm}$ のダイを使用した.
ハッシモ精米 (搗精步合 $90 \%$ )，玄米，発芽玄米および混合 A，混合 B の 5 種類を原料として試験を行った．各原料は 粉砕を行わず粒のまま投入した。膨化処理の操作条件は, バレル温度 $150^{\circ} \mathrm{C}$, スクリュー回転速度 $140 \mathrm{rpm}$, 原料供 給速度 $100 \mathrm{~g} / \mathrm{min}$, 圧力は $4.2 \mathrm{MPa}$ で行なった。

\section{5. 粉末試料の調製}

精米, 玄米等の原料および各膨化物の粉砕は, 粉砕機 (UDY, SFC-S1) により $1.0 \mathrm{~mm}$ スクリーンを用いて行 なった。

\section{6. 破断強度}

各膨化物の強度試験をテンシプレッサー（タケトモ電 機，TTP-50BX II）を用いて行った. 膨化試料を約 $4.0 \mathrm{~cm}$ 長にカットし，厚み方向の硬さを評価した。ロードセルの 負荷を $490.3 \mathrm{~N}$ （50 kgf），V 型プランジャーを用いて圧縮 速度は $2.0 \mathrm{~cm} / \mathrm{min}$ とした。

\section{7. 粒度分布}

粉末の粒度分布は粒度分布測定装置 (Coulter, LS) を用 い,ドライモジュールにより乾式測定を行った。

\section{8. 菌数の測定}

検体の調製は粉末試料 $10 \mathrm{~g}$ に減菌水 $100 \mathrm{~mL}$ を加え， 1 分間攪找したものを測定に用いた。

一般生菌数 : 標準寒天培地（日水製薬株式会社） $23.5 \mathrm{~g}$ を精製水 $1000 \mathrm{~mL}$ に加温溶解し, $121^{\circ} \mathrm{C}, 15$ 分間高圧蒸気 殺菌を行ない, これを約 $50^{\circ} \mathrm{C}$ で保ち, 検体を入れたシャー レに $20 \mathrm{~mL}$ 注入し, 検体と混和, 凝固させた. $36^{\circ} \mathrm{C}, 48$ 時 間培養し，発現したコロニーの数をカウントした。

大腸菌群 : デソキシコレート培地（日水製薬株式会社） $45.0 \mathrm{~g}$ を精製水 $1000 \mathrm{~mL}$ に加温溶解し，検体を入れた シャーレに約 $20 \mathrm{~mL}$ 分注し, 検体と混和, 凝固させた. $36^{\circ} \mathrm{C}, 24$ 時間培養し, コロニーの出現の有無を検討した.

\section{9. 粘度測定}

豊島らの方法 ${ }^{10)}$ で, 粘度特性試験を行った。 ラピッド・ ビスコ・アナライザRVA（Newport Sci-entific 社）によ り粘度曲線として求めた。使用試料量は， $3.5 \mathrm{~g}$ （水分含量 $14 \%$ 換算) で，水 $25 \mathrm{~mL}$ を添加して試験を行った．測定時 間は, 18.8 分間とした。温度条件は, 初期温度を $30^{\circ} \mathrm{C}$ にて 1 分間保持, 加熱条件は, $30 \sim 93^{\circ} \mathrm{C}$ まで, 3.9 分間とし, $93^{\circ} \mathrm{C}$ にて 7 分間保持した. 冷却条件は，93 $30^{\circ} \mathrm{C}$ まで 3.9 分間, 最終温度では, $30^{\circ} \mathrm{C}$ で 3 分間保持と設定した。

\section{0. 人工消化試験 11 )}

粉末試料 $5 \mathrm{~g}$ に $40^{\circ} \mathrm{C}$ の水を加えて全体量を $100 \mathrm{~g}$ とし, よく混合したものを試料とした。試料 $100 \mathrm{~g}$ を $3 \mathrm{~mol} / \mathrm{L}$ 塩 酸にて pH 2.0 に調整し， ウォーターバス中で $37^{\circ} \mathrm{C}$ に予熱

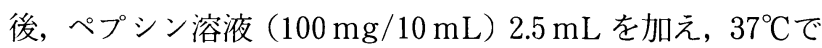
30 分間インキュベートした. 次に, $3 \mathrm{~mol} / \mathrm{L}$ 水酸化ナトリ ウムで pH 7.1 に調整し, $37^{\circ} \mathrm{C}$ に予熱後パンクレアチン溶 液 (30 mg/mL, 遠心分離後の上澄み液) $2.5 \mathrm{~mL}$ を加えた. パンクレアチン添加前および添加後 $5 ， 15 ， 30,60$ 分に反 
応液 $1 \mathrm{~mL}$ を試験管に採取し，直ちに沸騰湯浴中に 10 分 間つけて反応を停止させた。エ夕ノールを終濃度 $50 \%$ と なるように加えて, 18 時間冷蔵庫に保存した。保存後, 遠 心分離を行い，上澄み液を適度に希釈して，その中に含ま れる還元糖をソモギーネルソン法によりグルコースとして 測定し，希釈倍率を乗じて粉末試料 $1 \mathrm{~g}$ から生成される還 元糖量を求めた。

\section{1. 保存試験（貯蔵試験）}

温度 $28^{\circ} \mathrm{C}$ ，湿度 $75 \%$ に所定期間貯蔵した玄米粉および 膨化粉末の脂肪酸度を, 大坪らの比色法 ${ }^{12)}$ に準拠して測定 した.

\section{2. 遊離アミノ酸分析}

各試料の遊離アミノ酸含量の測定は, 試料 $0.5 \mathrm{~g}$ に $4 \%$ スルホサリチル酸水溶液 $2.5 \mathrm{~mL}$, エ夕ノール $2.5 \mathrm{~mL}$ をそ れぞれ加え, 2 分間覺找した後, 遠心分離を行った. その上 澄み液を $0.2 \mu \mathrm{m}$ のフィルターを通し抽出液とした。抽出 液をアミノ酸自動分析計（日立，L-8500A）により測定を 行った.

\section{3. 成分分析}

粉末試料の水分含量は加熱乾燥法 $\left(135^{\circ} \mathrm{C}, 1\right.$ 時間), 夕ン パク質含量は燃焼法（窒素・蛋白質分析装置, LECO 社 FP-528 型）により測定を行った．窒素-たんぱく質換算係 数は 5.95 , 大麦は 5.83 を用いた。脂質は酸分解法, 灰分は 直接灰化法, 糖質は水分, タンパク質, 脂質, 灰分および 食物繊維を 100 より減じて求める減算法, フィチン酸はバ ナドモリブデン酸吸光光度法，イノシトールは微生物定量 法, オリザノール及び総フェルラ酸は高速液体クロマトグ ラフ法，食物繊維は酵素-重量法により測定した。

\section{4. 動物試験および飼育条件}

(1) 血圧試験

6 週齢の高血圧自然発症ラット，雄を実験に供試した。 投与飼料は，膨化精米粉，膨化発芽玄米粉，混合膨化粉 B をそれぞれ正常食（AIN-76）に20\%置換したものとした。

動物入荷後, 1 週間正常食（AIN-76） で予備飼育の後, 試験対象物投与前日に体重および血圧測定を行い，各々有 意差の無いように膨化精米粉群 6 匹, 膨化玄米粉群 6 匹, 混合膨化粉 B 群 6 匹に分けて行なった．血圧測定は，ラッ トをホルダーに固定し， $38^{\circ} \mathrm{C} \pm 1{ }^{\circ} \mathrm{C}$ に保温した状態で tail cuff 法により尾動脈収縮期血圧を測定した。室温 $23 \pm$ $2{ }^{\circ} \mathrm{C}$, 湿度は $55 \pm 10 \% ， 12$ 時間の明暗サイクルの環境下で 個別のステンレス製代謝ケージを用い28日間飼育した。 飼料および水は自由摂取とし，投与期間中は，7日毎に体 重，摂餌量を測定し，0，14，28 日目に血圧測定を行った。 血圧測定は，群分け時と同様の測定法を用いた。

\section{(2) 肥満試験}

5 週齢の SD ラット，雌を実験に供試した．投与飼料は， 血圧試験と同様のものを使用し，各群 6 匹で行った。

動物入荷後, 予備飼育, 群分けの後, 卵巣摘出手術
（OVX）を行なった.OVX 処置後 1 週間後から各膨化粉末 置換 $20 \%$ の飼料を投与した，投与期間中 7 日毎，体重，摂 餌量の測定を行った。 28 日間の投与終了後，解剖を行な い, 体脂肪重量（後腹壁脂肪，腸管膜脂肪，腎周囲脂肪， 卵巣周囲脂肪）を測定した。

\section{5. パンおよび和菓子の試作}

パンの試作では，全量小麦粉を用いたパンの製法を基準 として，各膨化粉末，玄米，発芽玄米，混合 $\mathrm{A}$ ，混合 $\mathrm{B}$ を それぞれ $30 \%$ 配合した 4 種類のパンを以下のように調製 した。，小麦粉または配合粉 $290 \mathrm{~g}$ に上白糖 $16 \mathrm{~g}$ ，脱脂粉乳 $6 \mathrm{~g}$, 食塩 $5 \mathrm{~g}$, 無塩マーガリン $20 \mathrm{~g}$, ドライイースト $3 \mathrm{~g}$, 水 $231 \mathrm{~mL}$ を加え混合し，パン自動焼成機（象印マホービ ン株式会社，自動ホームベーカリー，パンくらぶ BB-GA 15）にて行なった.

和菓子の試作では，小麦まんじゅう粉（吉村穀粉株式会 社）を基準とし，玄米，発芽玄米，混合 A，混合 B の各膨 化粉末をそれぞれ $20 \%$ 配合し，以下のように調製した。 小 麦まんじゅう粉または各膨化粉末配合粉 $100 \mathrm{~g}$ に上白糖 $70 \mathrm{~g}$ を加え良く混合し，水 $44 \mathrm{~mL}$ を加え再度混合した。 そ の後, 30 分間冷蔵庫にて生地をねかし，餡 $30 \mathrm{~g}$, 生地 $15 \mathrm{~g}$ で包あんし，8 分間蒸した。

\section{6. 官能検查}

試作した各種パンおよび和菓子を評点法により官能検査 を行なった，検査項目は外観，生地の色，食感，香り，甘 さ，総合評価の 6 項目について評価を行なった。 小麦粉 100\%のパン，和菓子では，小麦まんじゅう粉を基準とし， 甘さの評価については, 強い-弱いについて, 他の項目につ いては良い-悪いの評価をそれぞれー 3 から+3の範囲で評 価を行なった。 パンのパネルは男女計 17 名, 和菓子のパネ ルを男女計 14 名で行った。

\section{実験結果および考察}

\section{1. 膨化原料の水分調整}

発芽玄米および発芽大麦は発芽処理時における浸漬のた め，水分含量が高くなる。このため，水分調整を行った. 八トムギ ${ }^{13)}$ やソルガム ${ }^{14)}$ は $15 \%$ 以下の水分で良好な膨化 性を示したと報告されており，本実験においても10\%か ら $13 \%$ の範囲で調整を行なった。水分調整時温度につい ては，鈴木らの報告 ${ }^{7)} よ り ， 100^{\circ} \mathrm{C}, 40^{\circ} \mathrm{C}, 15^{\circ} \mathrm{C}$ では，水分 調整時温度の差により, GABA 含量が異なり $15^{\circ} \mathrm{C}$ が最も 多かった。 また，乾燥温度 $100^{\circ} \mathrm{C}$ では粒子表面の多くが黒 褐色や茶褐色に変色し, $40^{\circ} \mathrm{C}$ の条件では発酵臭が感知され たことから，本実験においても発芽玄米および発芽大麦を $15^{\circ} \mathrm{C}$ にて水分調整を行った.

\section{2. 膨化物の特性}

（1）外観および水分

図 1 に玄米，発芽玄米，混合 A（発芽玄米・発芽大麦）, 混合 B（発芽玄米・発芽大麦・ビール酵母）を原料とした 


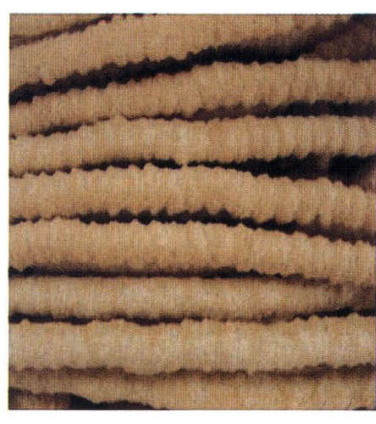

玄米

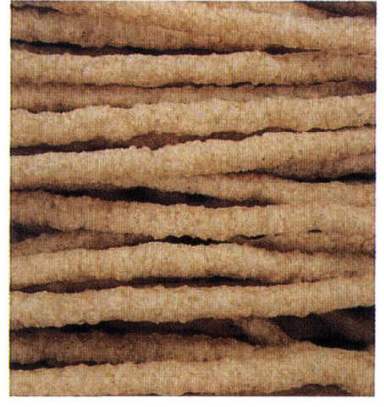

発芽玄米

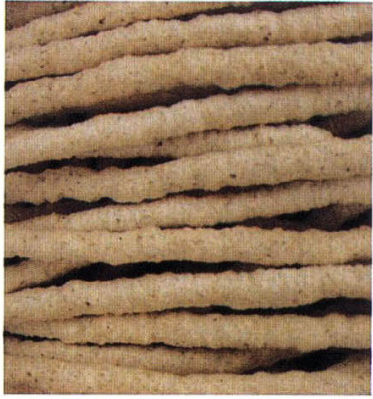

混合 $\mathrm{A}$

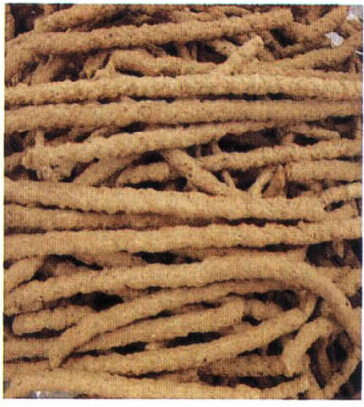

混合 B

図 1 膨化物の外観

各膨化物の外観を示した。 また，表 1 に各膨化物の一般成 分扔よび特性の測定結果を示した。各膨化物の水分は $5 \%$ から $8 \%$ の範囲であった。処理温度 $150^{\circ} \mathrm{C}$ での押し出しに より, 玄米では直径 $11.0 \mathrm{~mm}$, 発芽玄米は直径 $10.5 \mathrm{~mm}$, 混合 A は直径 $9.7 \mathrm{~mm}$, 混合 B では直径 $6.7 \mathrm{~mm}$ となった。 二軸エクストルーダーにより，膨化物を得るには，処理温 度が大きな要因の 1 つとして上げられる ${ }^{15)}$ 。本実験では良 好な膨化物を試作することが出来た。

(2) 破断強度

表 1 に破断強度の測定結果を示した。発芽玄米, 混合 A が同值で $5.6 \mathrm{kgf}$ と高く、ビール酵母を添加した混合 B は $3.8 \mathrm{kgf}$ と最む低い值となった。. 混合 B の膨化物は, ビール 酵母を $15 \%$ 配合しているために，測粉含量が低下してお り,これによって，も万くなったものと考えられる，玄米， 発芽玄米, 混合 A はスナック食品様食感でそのまま食す ることも可能と思われる，5種類の膨化物中では，混合 B が香ばしいか抢りが強かった。この要因として, 混合 B は 他の膨化物と比較して, 遊離アミノ酸や食物繊維が増加し ているため, アミノカルボニル反応等により, 焼成が進み やすい性質のものと考えられる.

\section{3. 膨化粉末}

(1) 粒度分布

大麦の胚乳部には，澱粉粒を取り囲むように食物繊維に 覆わ扎ており，微粉化が困難之されている，大麦の粒度分 布は $10 \sim 35 \mu \mathrm{m}$ 前後の画分之 $80 \sim 300 \mu \mathrm{m}$ の 2 つの異なる 群から構成され，一様な分布ではなかった。 10～ $35 \mu \mathrm{m}$ 前 後の画分は澌粉粒子で， $80 〜 300 \mu \mathrm{m}$ は粉砕されなかった 細胞片画分であると報告されている(16). 図 2 に玄米, 発芽 玄米，混合 $\mathrm{A}$ ，混合 $\mathrm{B}$ ， それぞれの膨化前，膨化後の粒度 分布の測定結果を示した。膨化前の発芽玄米の平均粒径は $124.5 \mu \mathrm{m}$ であるのに対し，膨化後では $117.6 \mu \mathrm{m}$ であった。 また，混合 B では膨化前の平均粒径は $107.6 \mu \mathrm{m}$ に対し， 膨化後では $97.7 \mu \mathrm{m}$ 之膨化粉末の中では, 最屯細かく粉砕 された。膨化前と膨化後の各膨化粉木の粒度分布を比較す ると玄米, 発芽玄米, 混合 A, 混合 B と屯に粗い粒径の体 積が減少し, 粒径の細かい部分へと移行し, 微粉化してい
表 1 膨化物の一般成分および特性

\begin{tabular}{lrccc}
\hline \hline & 立米 & 発芽立米 & 混合 $\mathrm{A}$ & 混合 B \\
\hline 水分含量 $(\mathrm{g} / 100 \mathrm{~g})$ & 5.5 & 8.1 & 7.2 & 6.1 \\
タンパク質 $(\mathrm{g} / 100 \mathrm{~g})$ & 6.7 & 6.6 & 9.6 & 15.4 \\
脂質 $(\mathrm{g} / 100 \mathrm{~g})$ & 3.3 & 3.6 & 3.3 & 3.1 \\
灰分 $(\mathrm{g} / 100 \mathrm{~g})$ & 2.9 & 1.6 & 1.3 & 1.3 \\
糖質 $(\mathrm{g} / 100 \mathrm{~g})$ & 78.1 & 74.9 & 66.5 & 62.8 \\
食物繊維 $(\mathrm{g} / 100 \mathrm{~g})$ & 3.5 & 5.2 & 12.1 & 11.3 \\
直径 $(\mathrm{mm})$ & 11.0 & 10.5 & 9.7 & 6.7 \\
破断強度 $(\mathrm{kgf})$ & 4.0 & 5.6 & 5.6 & 3.8 \\
\hline
\end{tabular}

水分含量 ; 加熱乾燥法により測定

タンパク質；燃焼法

脂質; 酸分解法

灰分; 直接灰化法

糖質; 水分, タンパク質, 脂質, 灰分㧍よび食物繊維を 100

上り減じて求める減算法.

食物繊維; 酵素-重量法

直径; 膨化製品の直径

破断強度 ; テンシプレッサーにより測定

た.

(2) 粘度特性

膨化前求よび膨化後の粘度曲線を図 3 に示す。大麦の粘 度が低いのは, モ千性品種のためと推測される. 膨化後は, 5 種類の試料之もに，ほ上んど粘度の上昇を示さなかった。 これは，港粉が膨化処理によってほぼ完全に糊化し，大部 分が可溶化しているためと思われ，鈴木ら》の結果之も一 致している.

(3) 消化試験

図 4 に膨化前試料（米，大麦）および膨化試料の消化試 験の測定結果走示す。本試験に供試した発芽玄米は，玄米 よりむ精米に近い消化性を示している。これは, 発芽処理 を施すことにより，外皮が柔らかくなり，測粉が少糖類に 分解されるため発芽玄米は玄米に比べ消化性が良くなるむ の上考えられる。 また，大麦屯モ千性裸麦のため，消化性 がよく, 発芽処理を施すことにより発芽玄米上同様に消化 性が向上しているむの之推測される。各膨化試料は，精米 よりもさらに消化性が良くなっていることが明らかになっ 
た.

\section{(4) 菌数検査}

表 2 に膨化前・後の一般生菌数および大腸菌群の測定結 果を示した. 膨化前試料では, 玄米, 大麦とも発芽処理を 行なうことにより，一般生菌数が増加した。他の原料と比 較しても発芽玄米の $9.6 \times 10^{5}(\mathrm{cfu} / \mathrm{g})$ が最も高かった。大 腸菌群では，精米，玄米，大考之も陽性であった。発芽玄 米および発芽大麦が陰性の理由では，発芽処理時に $0.1 \%$
次亜塩素酸ナトリウム水溶液にて浸漬を行なったためと考 えられる. 各膨化粉末の一般生菌数は，全て 300 末満であ り, 大腸菌群も全て陰性という結果となり, 膨化粉末の安 全性を証明する結果を得た。

\section{（5）保存試験}

温度 $28^{\circ} \mathrm{C}$, 湿度 $75 \%$ に 40 日間眝蔵した玄米粉および膨 化粉末粉の脂肪酸度の变化および水分の变化を図 5 に示 す. 玄米粉の場合, 貯蔵中に脂肪酸度が著しく増加するが,
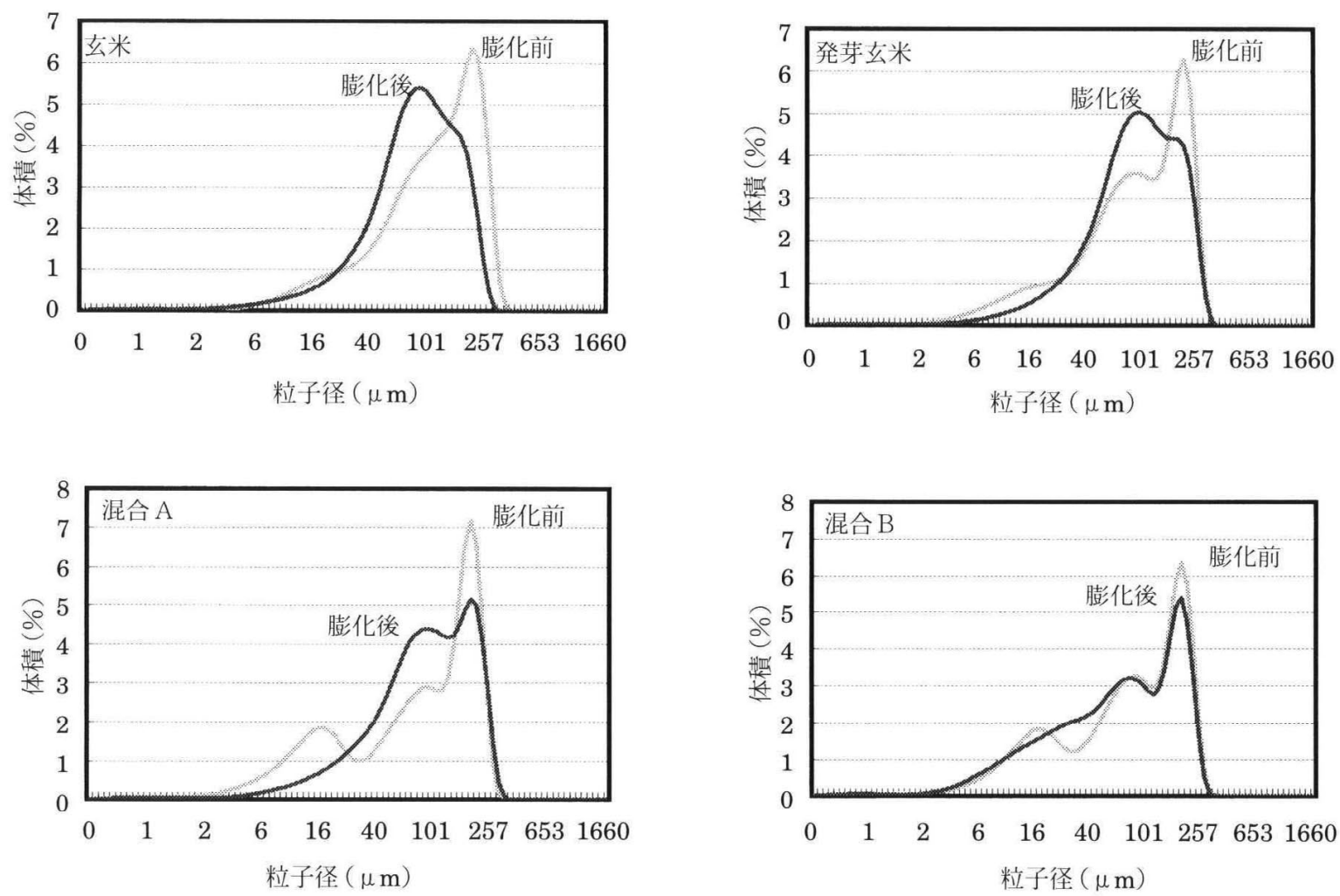

図 2 膨化粉末の粒度分布
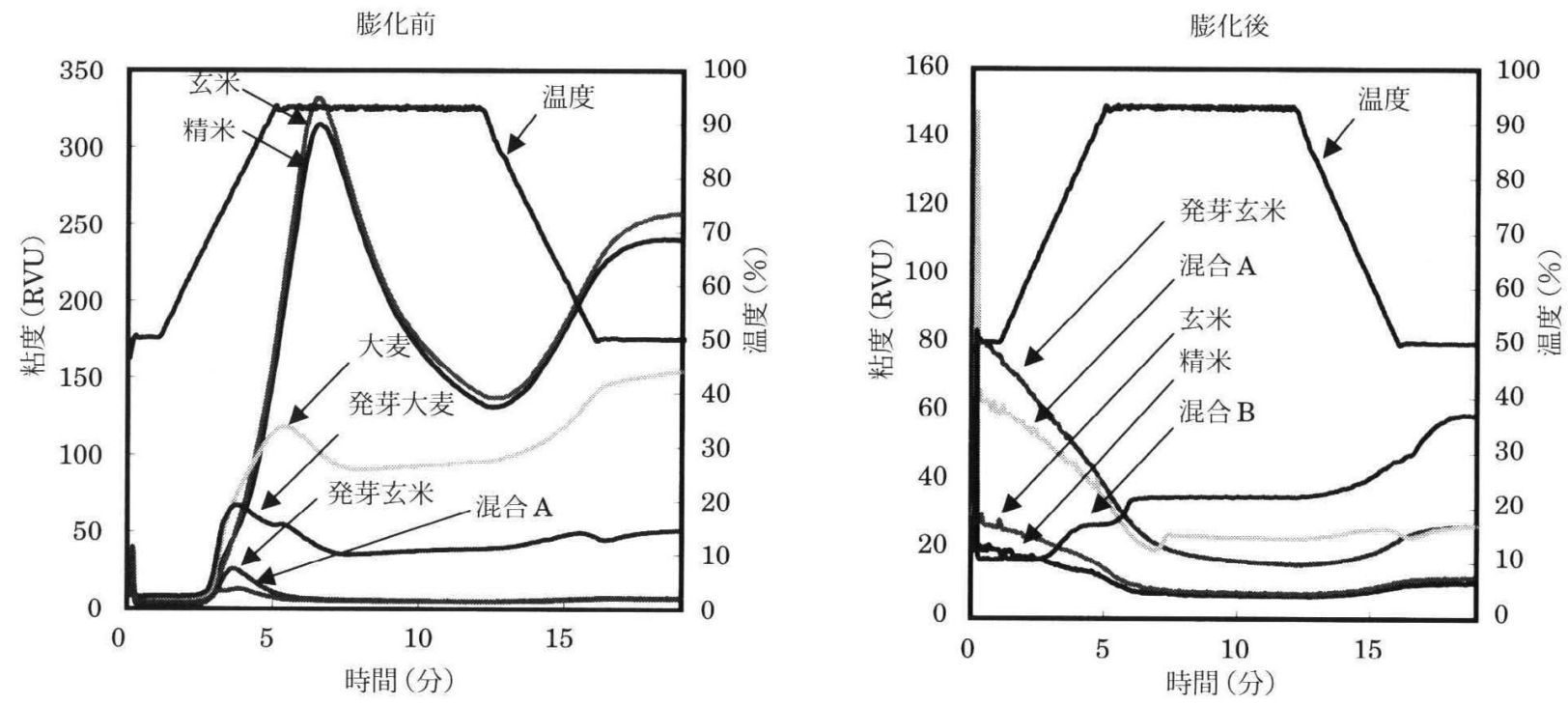

図 3 粘度曲線 

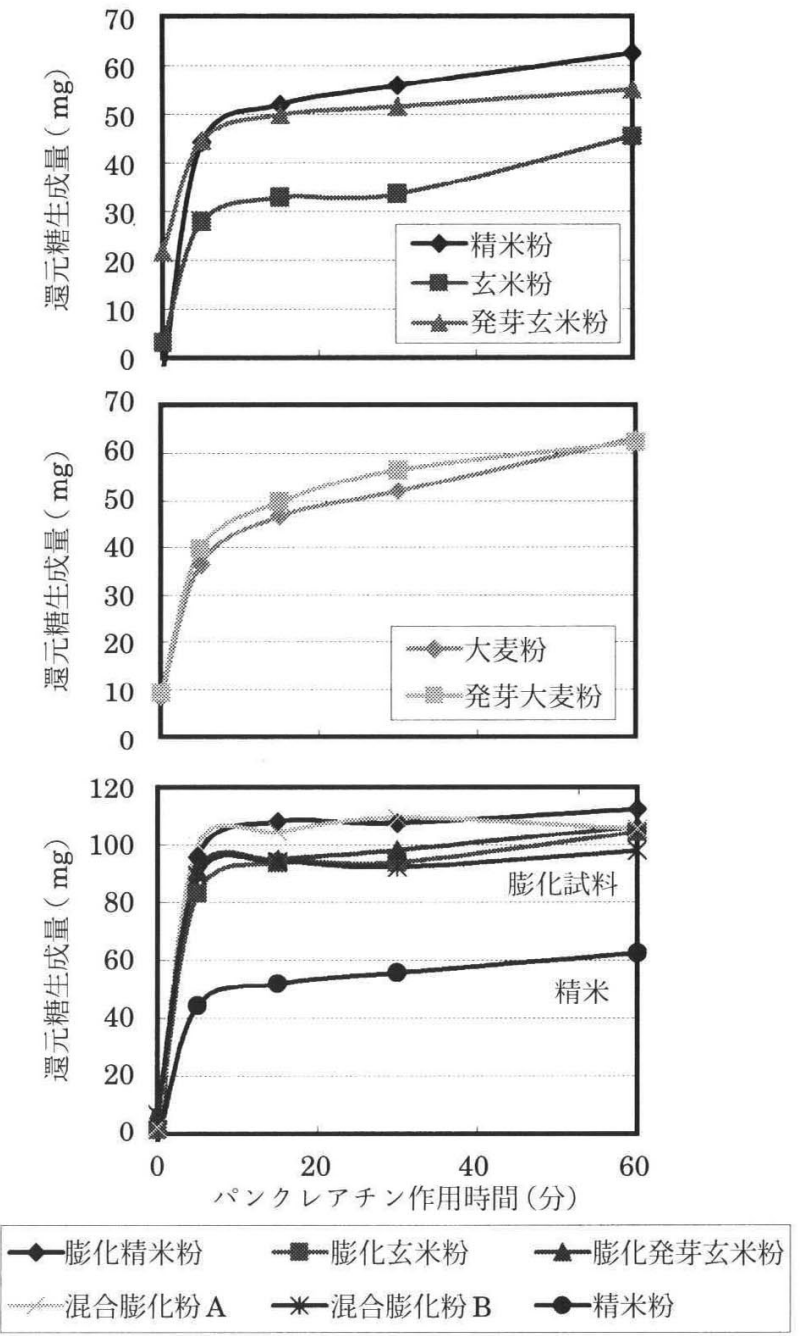

図 4 膨化前および膨化後の消化試験

表 2 原料および唼化粉末の菌数測定

\begin{tabular}{lcc}
\hline \hline \multicolumn{1}{c}{ 試料名 } & 一般生菌数 $(\mathrm{cfu} / \mathrm{g})$ & 大腸菌群 \\
\hline 精米粉 & $3.8 \times 10^{3}$ & + \\
玄米粉 & $8.8 \times 10^{4}$ & + \\
発芽玄米粉 & $9.6 \times 10^{5}$ & - \\
大麦粉 & $3.2 \times 10^{4}$ & + \\
発芽大麦粉 & $8.3 \times 10^{5}$ & - \\
粉末ビール酵母 & $2.5 \times 10^{3}$ & - \\
混合 $\mathrm{A}$ & $7.3 \times 10^{5}$ & - \\
膨化精米粉 & $<300$ & - \\
膨化玄米粉 & $<300$ & - \\
膨化発芽玄米粉 & $<300$ & - \\
混合膨化粉 $\mathrm{A}$ & $<300$ & - \\
混合膨化粉 $\mathrm{B}$ & $<300$ & - \\
\hline
\end{tabular}

一般生菌数 ; 標準寒天培地, $36^{\circ} \mathrm{C}, 48$ 時間培養後の生菌数.

大腸菌群; デソキシコレート培地, $36^{\circ} \mathrm{C}$, 培養後のコロニー 出現の有無.
各膨化粉末の場合は増加が極めて緩やかである。これは, 膨化好理によってリパーゼが失活し, 脂質の酵素分解が抑 制されたためと考えられる ${ }^{17)}$. 膨化処理により脂肪酸度の 増加が抑制されることが判った. 水分変化では, 膨化粉末 は港粉が糊化しているため吸湿性が強く，その特性に応じ た包装および保管が必要と考えられる.

\section{4. 膨化粉末の成分特性}

(1) 膨化処理による $\gamma-ア ミ ノ$ 酪酸含量

表 3 に乾物 $100 \mathrm{~g}$ あたりの膨化前後の GABA 含量を示 した. GABA は米肧芽に多く含まれ, 血圧降下作用, 脳機 能改善作用等が報告されている ${ }^{3)}$. 本実験に供試した発芽 玄米は市販されているあのと比較すると, 約 5 倍の GABA を含んでいた. 発芽玄米の $50.5 \mathrm{mg}$ に対し, 混合 $\mathrm{A}$ が $53.8 \mathrm{mg}$, 混合 B では $64.9 \mathrm{mg}$ とさらに多く含んでいた. 膨化後の GABA 含量は, 玄米では $1.62 \mathrm{mg}$, 発芽玄米では $51.7 \mathrm{mg}$, 混合 A および混合 B では $47.8 \mathrm{mg}$ となった. 膨 化処理による著しい減少の変化は見られず，高含量を保持 していた.

\section{（2）フィチン酸およびイノシトール含量}

表 4 にフィチン酸およびイノシトール含量の測定結果を 示した. フィチン酸には尿路結石, 腎結石などの予防, 抗 がん作用, また, イノシトールには肝脂肪, 動脈硬化予防, カルシウム吸収促進效果等が報告されている3 ${ }^{3)}$. 発芽大麦 には, フィチン酸が多く含まれている。混合膨化 A には $746 \mathrm{mg}$, 混合膨化 B では $748 \mathrm{mg}$ と発芽玄米 $613 \mathrm{mg}$ と比 較して $100 \mathrm{mg}$ 以上多く含まれていた。イイシトールです 同様に, 発芽玄米の $206 \mathrm{mg}$ 亡比較して, 混合膨化 A では $279 \mathrm{mg}$, 混合膨化 B の $284 \mathrm{mg}$ とさらに多く含まれてい た。

(3) オリザノール，フェルラ酸含量

表 4 にオリザノール，フェルラ酸含量の測定結果を示し た.オリザノールには自律神経失調症, 更年期障害等の医 療品原料として, また, 皮膚の老化防止等などがあり, 最 近では, 高温での抗酸化作用, 血中コレステロールの低下 作用を利用した食品の用途が拡大している3 は老化・発ガンの防止, 抗菌作用が報告されている. 発芽 玄米には，オリザノールが $36.5 \mathrm{mg}$ と多く含まれ，発芽大 麦には $1.5 \mathrm{mg} し$ か含まれていない. 発芽玄米と膨化発芽 立米との比較では, 膨化後では約 40\%に減少した. 混合膨 化 A には $8.7 \mathrm{mg}$, 混合膨化 B では $10.8 \mathrm{mg}$ であった. 発 芽大麦単体と比較すると多く含まれている. フェルラ酸 は，発芽大麦に多く含まれている，膨化発芽玄米の $53 \mathrm{mg}$ に比べて混合膨化 A には $92 \mathrm{mg}$, 混合膨化 B では $83 \mathrm{mg}$ と高い含量を示した。

(4) 食物繊維

表 4 に食物繊維の総量（水溶性，不溶性）の測定結果を 示した. 食物繊維は, 大腸癌予防, 糖尿病予防などの効果 が報告されている，発芽大麦の食物緎維は水溶性，不溶性 

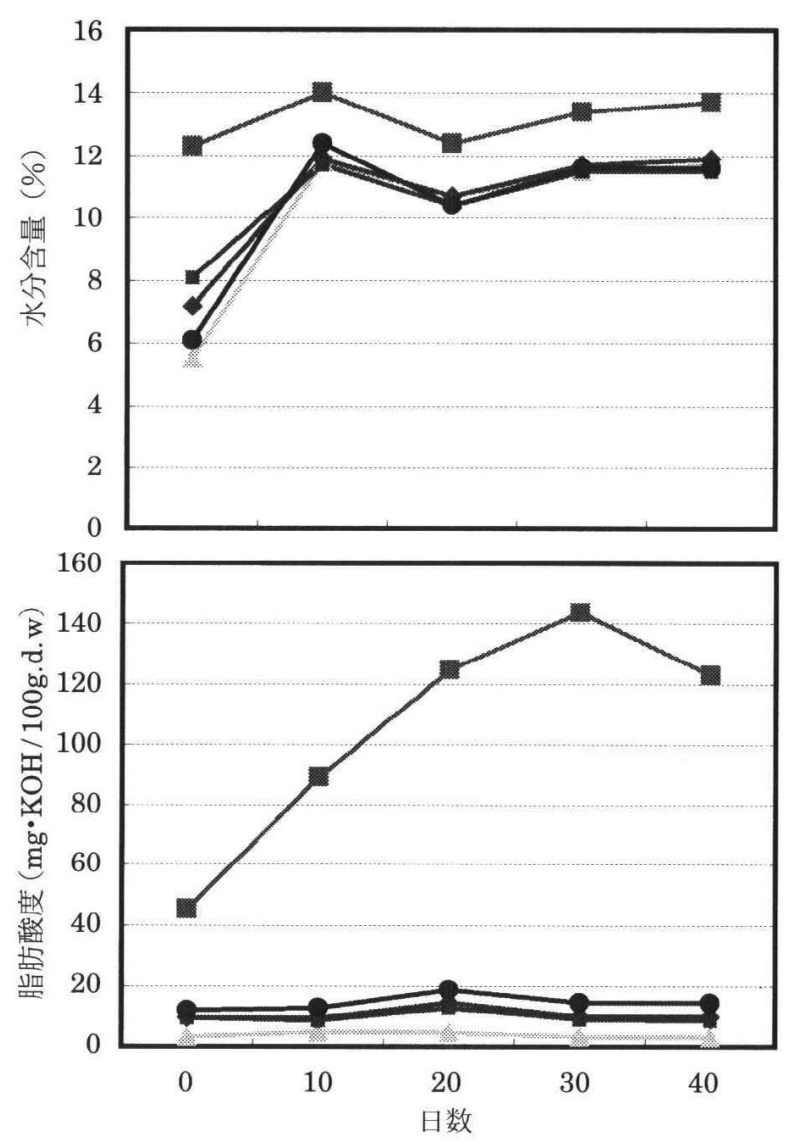

玄米粉 ……膨化玄米粉

一膨発芽玄米粉

混合膨化 1

混合膨化 2

図 5 貯蔵中の脂肪酸度および水分含量の変化

表 3 膨化前・膨化後の GABA 含量

\begin{tabular}{|c|c|c|}
\hline & \multicolumn{2}{|c|}{ GABA 含量 $(m g / 100 g)$} \\
\hline & 膨化前 & 膨化後 \\
\hline 精米 & 0.6 & 0.5 \\
\hline 玄米 & 1.1 & 1.6 \\
\hline 発芽玄米 & 50.5 & 51.7 \\
\hline 混合 A & 53.8 & 47.8 \\
\hline 混合 B & 64.9 & 47.8 \\
\hline
\end{tabular}

アミノ酸自動分析計（日立，L-8500A）により測定.

とバランス良く含まれている。総量での比較では発芽玄米 の 3 倍以上になる. 混合膨化 A では $12.1 \mathrm{~g}$, 混合膨化 B に は $11.3 \mathrm{~g}$ 含まれており, と屯に発芽玄米と比較し, 約 2 倍 以上多い。また, 膨化発芽玄米では, 水溶性食物緎維 $0.6 \mathrm{~g}$, 不溶性食物緎維 $4.6 \mathrm{~g}$ に対し, 混合膨化 A および混合膨化 $\mathrm{B}$ は, 水溶性・不溶性とバランス良く含まれている。混合 膨化製品は，膨化発芽玄米に比べて食物繊維が強化されて いると言える。

\section{5. 動物試験}

(1) 高血圧試験

表 5 に体重の推移を示し, 図 6 には 0,14, 28 日目の収 縮期血圧測定の結果を示した。試験期間中の高血圧自然発
症ラットの体重推移では, 膨化精米粉 $20 \%$ 置換との比較 では膨化発芽玄米粉 $20 \%$ 置換で 21 日目（P<0.05），混合 膨化粉 B20\% 置換で 7，14，21，28 日目 $(\mathrm{P}<0.05 ）$ に有意 に低い值を示した。 また，摂䬣量には有意差は認められな かった．収縮期血圧測定は，膨化精米 $20 \%$ 置換との比較に 対し，28 日目に膨化発芽玄米粉 $20 \%$ 置換 $(P<0.05)$, 混合 膨化粉 $\mathrm{B} 20 \%$ 置換 $(\mathrm{P}<0.01)$ で有意差を示した. 高血圧抑 制と関わりがあるとされているコレステロールの上昇抑制 作用は，食物繊維の中でも，水溶性食物繊維の穀物ガム質 といわれている. とくに大麦の食物繊維には，この穀物ガ ム質が多く含まれている．混合膨化粉 B20\%置換では，発 芽大麦を混合することにより水溶性食物繊維が増加した効 果上考えられる. 膨化発芽玄米粉および混合膨化粉 B は, 高血圧抑制作用を有することが明らかになった。

(2) 肥満試験

表 6 に体重の推移を示し, 図 7 に体脂肪量の結果を示し た. 試験期間中の体重および掑餌量の推移では有意差は認 められなかった．体脂肪量では，脰化精米 $20 \%$ 置換と比較 L，膨化発芽玄米粉 20\% 置換，混合膨化粉 B20\% 置換で は，有意差は認められなかった。

乾燥ビール酵母を，5\%添加した飼料と通常の飼料で飼 
育したマウスの 16 ケ月間の比較調査では，雌では試験開 始 2 ケ月頃より, 雄では 4 ケ月頃より酵母を与えた群の体 重増加が鈍化し，雌においては 2 ケ月目から 4 ケ月目にか けての内臓脂肪量の急激な増加が酵母の摂取により軽減さ れたという報告がある ${ }^{6)}$. 今後は長期にわたる動物評価が 必要であると考えられる。

\section{6. 膨化粉末配合のパンおよび和菓子}

(1) 性 状
図 8 に試作した食パンの断面図を示した。パンの外観で は，膨化発芽玄米および混合膨化 A は小麦粉 $100 \%$ と比較 し，若干見劣りするものの良好な結果が得られた。混合膨 化 B は, 全体のデンプン量の減少により膨らまなかったと 推測される. 断面の比較では, 各膨化粉末配合パンは気泡 が多く，生地が粗く感じられた。

(2) 成分分析

表 7 に食パンの遊離アミノ酸含量の測定結果を示した。

表 4 原料および膨化粉末の機能性成分

\begin{tabular}{|c|c|c|c|c|c|c|}
\hline & 発芽玄米 & 発芽大麦 & 膨化精米粉 & 膨化発芽玄米 & 混合膨化 A & 混合膨化 B \\
\hline フィチン酸（mg/100 g） & 613 & 969 & 32 & 674 & 746 & 748 \\
\hline イノシトール $(\mathrm{mg} / 100 \mathrm{~g})$ & 206 & 378 & 42 & 207 & 279 & 284 \\
\hline オリザノール（mg/100 g $)$ & 36.5 & 1.5 & 検出せず & 14.2 & 8.7 & 10.8 \\
\hline 総フェルラ酸 $(\mathrm{mg} / 100 \mathrm{~g})$ & 54 & 130 & 11 & 53 & 92 & 83 \\
\hline 食物繊維総量（g/100 g） & 5.1 & 19.1 & 0.8 & 5.2 & 12.1 & 11.3 \\
\hline 水溶性食物緎維（g/100 g） & 0.6 & 6.8 & 0.5 未満 & 0.6 & 3.8 & 4.0 \\
\hline 不溶性食物繊維（g/100 g） & 4.5 & 12.3 & 0.8 & 4.6 & 8.3 & 7.3 \\
\hline
\end{tabular}

各種生理機能性成分在本文, 13 「試料扰上び実験方法」の方法で測定. 混合膨化 A ; 発芽玄米上発芽大麦を $1: 1$ に配合して混合膨化.

混合膨化 B ; 発芽玄米 4.25 , 発芽大麦 4.25 , ビール酵母 1.5 に配合して混合膨化.

表 5 高血圧試験による体重の推移

$(\mathrm{g})$

\begin{tabular}{|c|c|c|c|c|c|c|}
\hline \multirow[t]{2}{*}{ 投与日数 } & & 0 & 7 & 14 & 21 & 28 \\
\hline & & SD & SD & SD & $\mathrm{SD}$ & $\mathrm{SD}$ \\
\hline 膨化精米粉 $20 \%$ 置換 & $(n=6)$ & $123.2 \pm 11.30$ & $216.6 \pm 26.49$ & $283.5 \pm 14.97$ & $322.6 \pm 17.61$ & $340.7 \pm 16.07$ \\
\hline 膨化発芽玄米粉 20\% 置換 & $(n=6)$ & $124.4 \pm 8.08$ & $192.6 \pm 14.26$ & $271.3 \pm 13.80$ & $308.2 \pm 14.99$ & $322.1 \pm 17.12$ \\
\hline 混合膨化粉 B20\% 置換 & $(n=6)$ & $124.6 \pm 9.25$ & $186.3 \pm 13.52^{*}$ & $260.4 \pm 10.50^{*}$ & $302.6 \pm 6.61^{*}$ & $317.0 \pm 5.99^{*}$ \\
\hline
\end{tabular}

6 週齢の高血圧自然発症ラット各 6 匹での飼育試験結果.

膨化精米に対する有意差 ${ }^{*}: p<0.05$

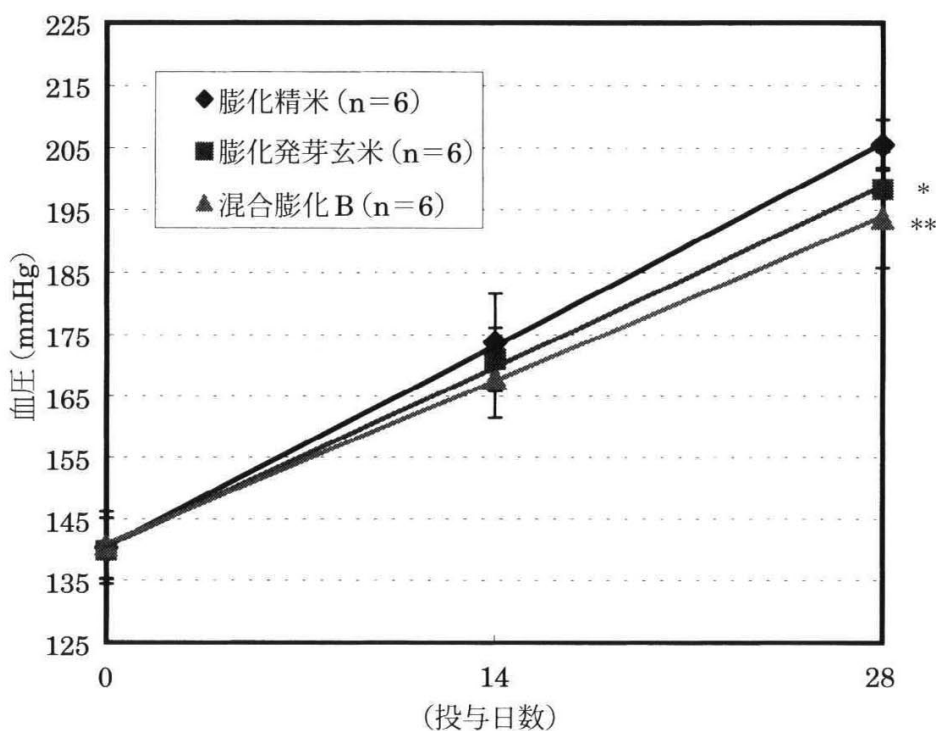

図 6 収縮期血圧の推移

投与 28 日目による膨化精米に対する有意差 ${ }^{*}: p<0.05,{ }^{* *}: p<0.01$ 


\begin{tabular}{|c|c|c|c|c|c|c|}
\hline \multirow[t]{2}{*}{ 投与日数 } & & 0 & 7 & 14 & 21 & 28 \\
\hline & & $\mathrm{SD}$ & $\mathrm{SD}$ & $\mathrm{SD}$ & $\mathrm{SD}$ & SD \\
\hline 膨化精米粉 20\% 置換 & $(n=6)$ & $194.6 \pm 8.21$ & $212.7 \pm 7.80$ & $230.5 \pm 8.13$ & $244.6 \pm 8.21$ & $254.1 \pm 7.97$ \\
\hline 膨化発芽玄米粉 20\% 置換 & $(n=6)$ & $197.3 \pm 10.18$ & $216.9 \pm 8.53$ & $231.9 \pm 9.77$ & $249.4 \pm 9.81$ & $266.8 \pm 8.56$ \\
\hline 混合膨化粉 B20\% 置換 & $(n=6)$ & $191.0 \pm 7.31$ & $216.1 \pm 6.86$ & $230.6 \pm 6.58$ & $245.4 \pm 7.07$ & $266.8 \pm 7.71$ \\
\hline
\end{tabular}

5 週歯の SD ラット各 6 匹での飼育試験結果.

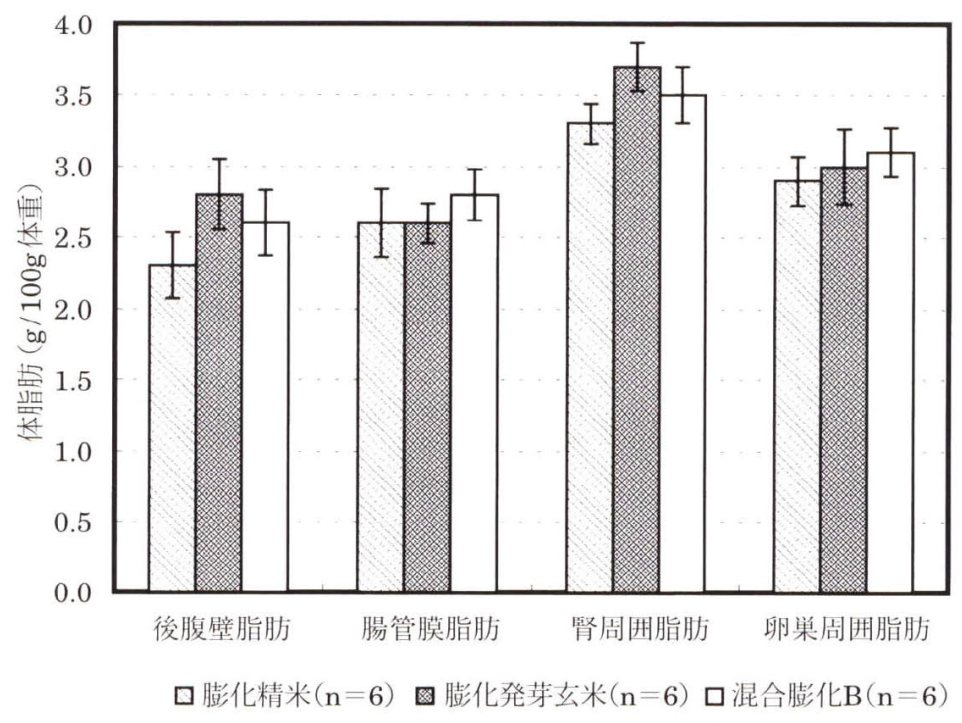

図 7 体脂肪の变動

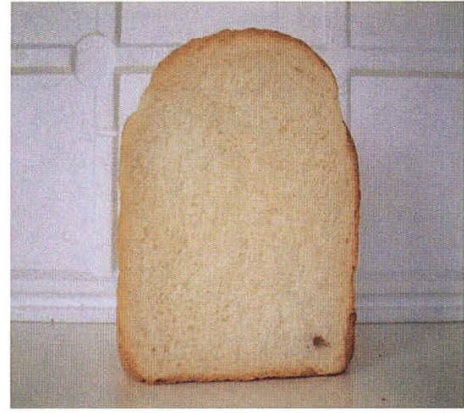

小麦粉

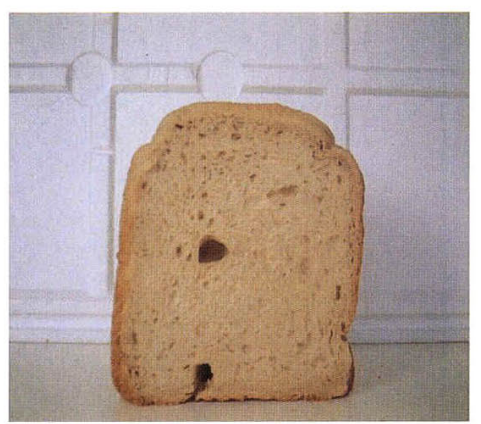

混合 A 30\%配合

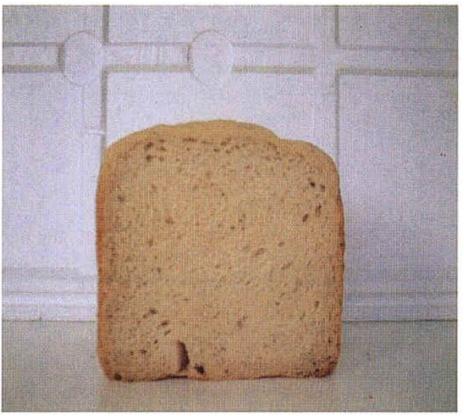

玄米 $30 \%$ 配合

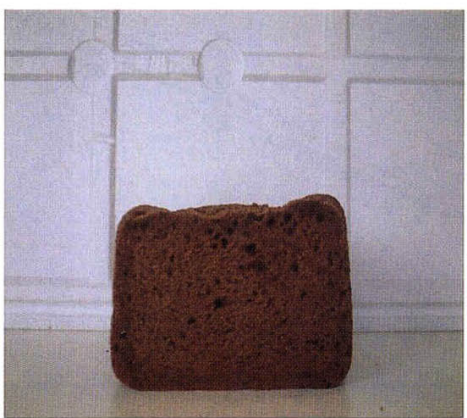

混合 B 30\%配合

図 8 膨化粉末配合パンの外観

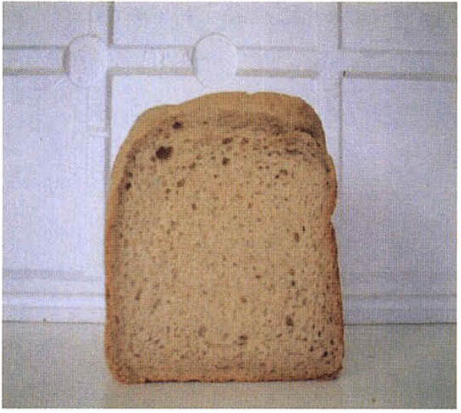

発芽玄米 $30 \%$ 配合 
混合膨化 A $30 \%$ 配合パンと混合膨化 B30\% 配合パンは, 小麦粉パンおよび膨化玄米 $30 \%$ 配合パンに比べ GABA が 約 3 倍以上の含量で, 発芽および混合膨化の効果が確認さ れた。

呈味関連の成分とし，グルタミン酸 (旨み), アスパラギ ン酸（旨み），グリシン（甘み），アラニン（甘み）を測定 した，小麦粉パン，膨化玄米 $30 \%$ 配合パン, 膨化発芽玄米 $30 \%$ 配合パン, 混合膨化 A30\% 配合パンでは, 各呈味成分 に大きな変化は現れなかったが，混合膨化 B30\%配合パン では, 各呈味成分の増加が確認され, 中であアラニン（甘 み）が多く含まれていた。

\section{(3) 官能検査}

図 9 に食パンの官能検査の結果を示した。小麦粉パンと の比較では，発芽玄米 $30 \%$ 配合パンでは，甘味があり（P $<0.05)$ ，食感が良く（P<0.05），総合評価に㧊いても有意 に優れていた $(\mathrm{P}<0.05)$. 混合膨化 $\mathrm{A} 30 \%$ 配合パンでは,
食感（P<0.05）と甘さ $(P<0.05)$ が有意に優れていた. 混合膨化 $\mathrm{A} 30 \%$ 配合パンの外観は若干見劣りするもの の, GABA 含量は約 3 倍以上の含量であり, 食味, 食感は きわめて良好であった，混合膨化 B30\%配合パンは，外観 および官能検査の結果, 小麦粉パンに比べて劣るむのの, GABA 含量では約 3 倍以上，さらに各呈味成分の増加が 確認された。これらのことから, 混合膨化粉末 $\mathrm{A}$ は, 一般 のパン用粉として充分利用可能と考えられる．混合膨化粉 末 B は, 一般用では困難であるが, 高澮者食, 病態食に使 用できる可能性があると思われる.

各膨化粉末 $30 \%$ 配合パンは，小麦粉に比べ柔らかく， しっとりとした食感という評価を得ることが出来た。

図 10 に, 和菓子 (まんじゅう) の官能検査の結果を示し た。混合膨化 B20\% 配合の和菓子は, 香りが良く（P< $0.05)$ ，食感 $(P<0.05)$ で有意に優れていた.

以上の結果より, 高温高圧加工により微粒粉砕が可能と

表 7 食パンの遊離アミノ酸含量

\begin{tabular}{|c|c|c|c|c|c|}
\hline & 小麦粉 & 膨化玄米 & 膨化発芽玄米 & 混合膨化 A & 混合膨化 B \\
\hline GABA & 3.1 & 0.3 & 11.6 & 11.1 & 11.7 \\
\hline グルタミン酸 & 14.1 & 13.2 & 11.6 & 11.0 & 39.2 \\
\hline グリシン & 3.3 & 2.9 & 3.1 & 3.5 & 10.6 \\
\hline アラニン & 22.5 & 24.5 & 26.1 & 21.5 & 223.2 \\
\hline アスパラギン酸 & 2.2 & 2.7 & 1.9 & 2.2 & 31.7 \\
\hline 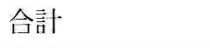 & 45.3 & 43.5 & 54.3 & 49.3 & 316.4 \\
\hline
\end{tabular}

アミノ酸自動分析計（日立，L-8500A）に上り測定.

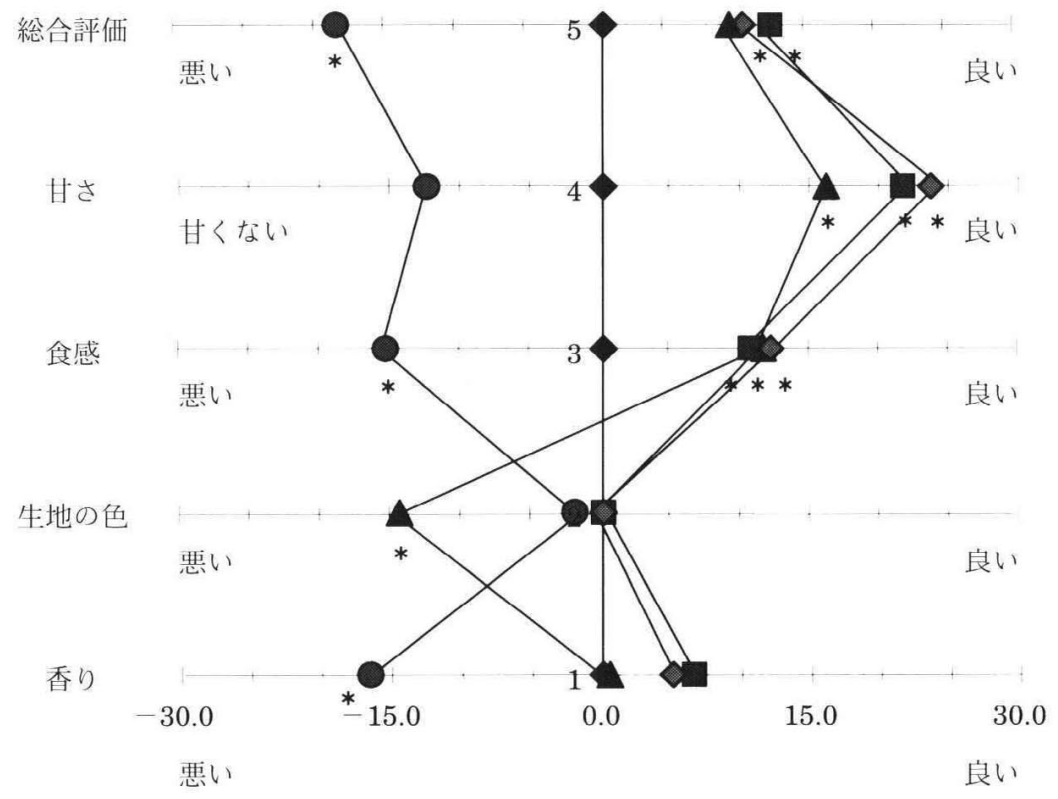

一小麦粉 100\% 日膨化玄米30％・膨化発芽玄米30％、混合膨化A30％・混合膨化B30％

$*: \mathrm{t}$ - 検定, $5 \%$ 危険率

図 9 


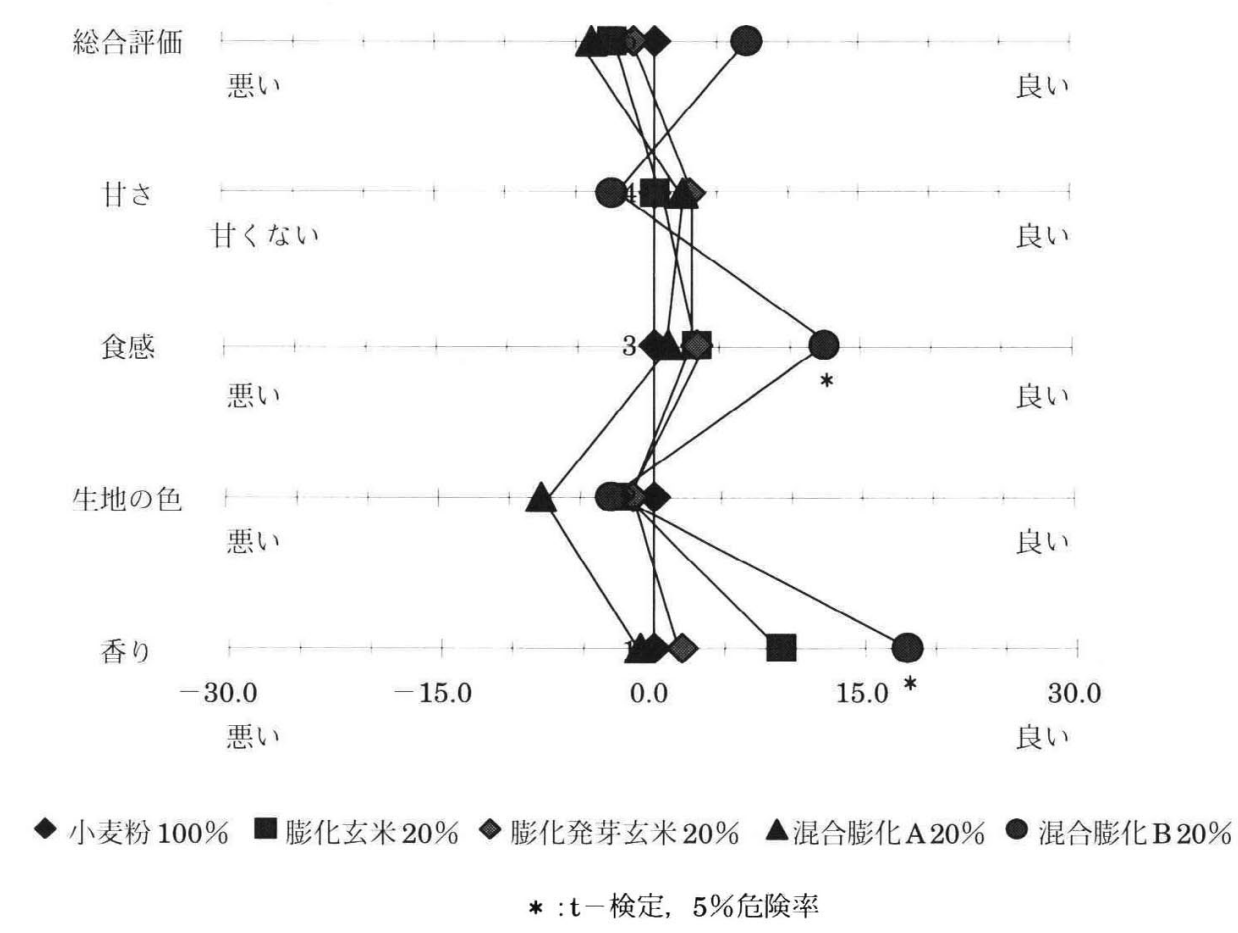

図 10 和菓子の官能検查結果

なり, 殺菌効果作用, 脂肪酸度の増加抑制による品質保持, 消化性向上による品質の向上が認められた。また，発芽玄 米・発芽大麦・ビール酵母の混合膨化粉末は，玄米执よび 発芽玄米上りも機能性成分が強化され，食味も良好な素材 であることが明らかになった。米の用途拡大において，発 芽後の混合膨化処理粉砕は有用な製造技術であることが確 認された.

本研究により開発された機能性成分に富んだ米・大麦・ 酵母混合膨化粉末は，高血压抑制作用が確認され，米・大 麦混合膨化粉末の用途として，パン用粉，和菓子用原料粉 等に利用が可能と考えられる.

\section{要 約}

発芽玄米および発芽大麦を配合した混合 $\mathrm{A}$ ，また，発芽 玄米, 発芽大麦さらにビール酵母古加えた混合 $\mathrm{B}$ を 2 軸工 クストルーダーにより膨化処理を行った. 生理機能性およ び消化性に優れた多目的食品素材の開発を試みた。得られ た結果は以下の通りである.

(1) 混合膨化 B の膨化粉末では，粒径が膨化前 $107.6 \mu$ $\mathrm{m}$ に対し, 膨化後では $97.7 \mu \mathrm{m}$ となり, 各膨化粉末は粗い 粒径の体積が減少し，粒径の細かい部分へ上移行した。

(2) 発芽処理工程により，発芽玄米および発芽大麦の一 般生菌数が多くなるが，膨化処理により $300(\mathrm{cfu} / \mathrm{g})$ 末満 となり，大腸菌群も検出されなくなった.

（3）発芽玄米, 混合 A, 混合 B の膨化粉末は, 精米粉よ り屯消化性が優れていることが確認された。

（4）膨化処理により，脂質の分解が抑制されることによ
り脂肪酸度が増加しなかった。

（5）各混合膨化製品は，膨化発芽玄米と比べてフィチン 酸, イノシトール，フェルラ酸，食物繊維を多く含有して いた。

（6）高血压自然発症ラットを用いた血圧試験では，投与 日数 28 日目において，膨化精米粉 $20 \%$ 置換に対し，膨化 発芽玄米粉, 混合膨化粉 B が有意に低い值を示した．膨化 発芽玄米粉, 混合膨化粉 B は高血圧抑制作用を持つことが 明らかになった。

（7）官能検査においては, 混合膨化 A30\% 配合パンは, 小麦粉パンと比較し食感 $(\mathrm{P}<0.05)$ と甘さ $(\mathrm{P}<0.05)$ で有 意に優れていた. 各膨化粉末 $30 \%$ 配合パンは, 小麦粉に比 ベ柔らかく，しっとりとした食感という評価を得ることが 出来た。また，和菓子の官能検査では，混合膨化 B20\% 配 合は，小麦まんじゅうとの比較で香り $(\mathrm{P}<0.05)$ ，食感 $(\mathrm{p}$ <0.05）で有意に優れていた。 いずれも食品として高い評 価が得られた。

本研究は, 農林水産省総合食料局「平成 15 年度米加工品 新技術研究開発事業」の一部で実施されたあのである.

本研究を進めるにあたり, 試験用エクストルーダーを使 用させて頂きました独立行政法人 食品総合研究所 製造 工学研究室室長 五十部誠一郎博士，機能性成分の分析に 御協力頂きました財団法人 日本食品分析センターに感謝 致します。 


\section{文献}

1）三枝貴代, 堀野俊郎, 森隆, 水浸漬時の米肧芽での $\gamma-ア$ ミ)酪酸 (Gaba) の激増, 中国農業試験場研究成果情報 (1993).

2）大坪研一, 穀類中の栄養機能性成分の特長と利用の可能性, FOOD Style 21，6，44-47 (2002).

3）築野卓大, 米糠・米油の市場動向について, 食品加工技術, 22, 1-11 (2002)

4）科学技術庁資源調査会，五訂日本食品標準成分表，30-31 (2000).

5）高瀬幸子, 栗原長代, 道喜美代, 穀類, 特に大麦の血漿コレ ステロールに及ぼす影響，栄養と食料，23，426-429 (1970).

6）安江正明，ビール酵母の肥満予防効 BIOINDUSTRY， 20, 38-43 (2003).

7）鈴木啓太郎, 岡留博司, 奥西智哉, 中村澄子, 大坪研一, 発 芽玄米の 2 軸エクストルージョンによる食品素材化，食科 工, 50, 474-482 (2003).

8）進藤三幸，相原 宏，はだか麦あられの油ちょう膨化特性, はだか麦の利用加工技術の確立研究, 愛媛県工技研究報告, 26, 43-49 (1988).

9）大坪研一，岩崎哲也，八トムギ・酵母混合膨化製品の品質 について，日食工誌，37，144-147（1990）。

10）豊島英親, 岡留博司, 大坪研一, 須藤 充, 堀末 登, 稲津
修，成塚彰久，相崎万裕美，大川俊彦，井八内直良，不破英 次，ラピッド・ビスコ・アナライザーによる米粉粘度特性 の微量迅速測定方法に関す万其问試験，食科丁，44，579584 (1997).

11）新原律子, 三好華世, 粘抢よび米飯のテクスチャーとデン プンの消化性, 高知大学教育学部研究報告第 3 部, 55, 1-14 (1997).

12）大坪研一, 柳瀬 肇, 石間紀男, 比色法に上る米の脂肪酸度 測定, 貯蔵による米の品質変化とDuncombe 法を改良し て測定した脂肪酸度との関係について, 食品総合研究所研 究報告, 51，59 65（1987）。

13）大坪研一, 柳瀬 肇, 橋本勝彦, 豊島英親, 户谷昭夫, 八卜 ムギの膨化性㧍よびその改良，日食工誌，31，596-603 (1984).

14）大坪研一，柳本正勝，柳瀬 肇，ソルガムの膨化とその改 良，日食工誌，35，321-326（1988）。

15）五十部誠一郎, 野口明徳, 2 軸エクストルーダーによる食品 素材の製造，日食工誌，34，456-461（1987）。

16）金井政人，楠正 敏，大麦粉の分級処理による高食物瀻維 两分の分取条件, 新潟県食品研究所研究報告, 31，9-13 (1996).

17）大坪研一, 柳瀬肇, 膨化ハトムギの性状について, 日食丁. 誌，32，101-107 (1985).

(平成 16 年 3 月 29 日受付, 平成 16 年 8 月 6 日受理) 